\title{
Sales Catalogues of Jewish-Owned Private Libraries in the Dutch Republic during the Long Eighteenth Century: A Preliminary Overview
}

\author{
Anna E. de Wilde
}

Scholars have long recognised that the study of early modern sales catalogues and private libraries requires more attention within Hebrew bibliography and Jewish book history. ${ }^{1}$ Despite some valuable case studies, a comprehensive historical overview and commonly accepted typologies are lacking. The source material is puzzling in its diversity and complexity, and there are many details that are unknown about historical bookselling and cataloguing practices. Because of these ambiguities it is essential to first address the question of how to define a Jewish book catalogue, and to gain an understanding of the catalogue genre itself, before being able to attempt a detailed study of the books listed in sales catalogues. ${ }^{2}$ Thus, the focus is particularly on the type and form of the catalogues, rather than their content.

As a first step toward understanding what a Jewish library catalogue is, I provide here an overview of printed sales catalogues that belonged to Jewish owners, living in the Dutch Republic during the long eighteenth century. This 'long' century is defined as the period from circa 1665 to 1830 , encompassing the years associated with the Enlightenment movement. ${ }^{3}$ First a typological reflection on the source material will be presented in this article. Then, I examine the catalogues of Jewish booksellers and printers, and discuss the often confusing practices in the book trade and printing business within the Jewish

1 Yaacob Dweck, 'What is a Jewish book?', AJS Review, 34 (2010), pp. 367-375, esp. p. 374. Marvin J. Heller, 'The Hebrew book trade as reflected in book catalogues', Quaerendo, 26 (1996), pp. 245-257, esp. p. 245. This project has received funding from the European Research Council (ERC) under the European Union's Horizon 2020 research and innovation program under grant agreement No. 682022 .

2 Cf. Dweck, 'What is a Jewish Book?'.

3 This research is part of the MEDIATE project, that seeks to study the circulation of books and ideas in eighteenth-century Enlightenment Europe, see A.C. Montoya, 'Middlebrow, Religion, and the European Enlightenment: A New Bibliometric Project, MEDIATE (16651820)', French History and Civilization, 7 (2017), pp. 66-79. 
communities of the Dutch Republic. This will be followed by a study of the relationship between auctions and sales catalogues. The central part of this article focuses on private library catalogues and their various types and developments during the eighteenth century. I will address the following questions. What kind of catalogues were printed? Who were the owners of the collections? How were the catalogues organised, how many books do they hold, and in which languages are the books listed? And what developments can be distinguished over the years?

For this research I use data from the inventory 'Book Sales Catalogues of the Dutch Republic, 1599-180o', that was started by book historian Bert van Selm and that is currently forming the basis for two ERC funded databases, mediate (Middlebrow Enlightenment Disseminating Ideas, Authors and Texts in Europe, $1665^{-1830}$ ) and BIBLIO (Bibliography of Individual Book and Library Inventories Online, $\left.1665^{-1830}\right){ }^{4}$ This inventory is not complete with regard to the Jewish material, therefore I have added additional catalogues to Van Selm's corpus. Furthermore, I also included data covering the period 180o-1830. So far, this results in circa 6o sales catalogues of book collections that belonged to Jewish owners and were auctioned in the Dutch Republic. A list of all the Jewish-owned sales catalogues can be found in the appendix. Six sales catalogues are of Jewish booksellers or printers, of which two are only known by references. A total of 21 private library sales catalogues of known owners have been preserved. Five others are known only by references, as their location is currently unknown. Furthermore, I distinguish 25 anonymous sales catalogues that appear to be of private libraries, for reasons I detail below.

\section{Book Lists, Inventories and Catalogues: A Typological Reflection}

Hebrew book lists and inventories of Hebrew and Jewish books have a long history. The oldest known were found in the genizah (storeroom) of the Ben Ezra Synagogue in Cairo. Some of these book lists contain prices and appear to have been booksellers' catalogues. Others seem to have been compiled for auctions after an owner's death, such as the collection of Abraham he-Hasid of Cairo, listing among others 27 Hebrew books, which were sold by the Jewish

4 Bert van Selm, 'Een menighte treffelijkcke boeken'. Nederlandse boekhandelscatalogi in het begin van de zeventiende eeuw (Utrecht: HEs, 1987). Book Sales Catalogues Online - Book Auctioning in the Dutch Republic, ca.1500-ca. 1800 (Leiden: Brill, 2015) http://primarysources .brillonline.com/browse/book-sales-catalogues-online (henceforth: Bsco). 
court after he passed away in 1223.5 With the invention of printing, when books began to be cheaper and more widely available, a proper trade in Hebrew and Jewish books emerged. Book lists were occasionally used by publishers to advertise their publications. For instance, the famous publisher Daniel Bomberg presented a list of 75 Hebrew books printed by himself and other printers to the Swiss scholar Conrad Gesner, which the latter printed in Latin in his Pandectae (1548). ${ }^{6}$

The first non-Jewish printed book sales catalogues, in the modern sense, emerged in the Dutch Republic at the end of the sixteenth century. These were booklets with lists of books that would be sold, often at an auction. The aim of a bookseller was to make a profit. Consequently, the descriptions of the listed books were not always complete. During the seventeenth century the first catalogues containing book collections belonging to Jewish owners were published. Initially, these catalogues were printed and sold primarily by Christian booksellers. Soon, Portuguese Jewish printers and booksellers in Amsterdam followed the Dutch example, when they issued the first sales catalogues of their retail stock. In the eighteenth century, Jewish printers also started publishing sales catalogues of private libraries.

In research on Jewish or Hebrew libraries, scholars speak interchangeably of 'catalogues', 'lists', and 'inventories' without making explicit whether they refer to printed catalogues, manuscript lists of books made for domestic use, or probate inventories. ${ }^{7}$ In actual practice, it seems that the handwritten material has received most attention. While over the years several scholarly editions of booklists and inventories, and studies of libraries have been published, only a handful make use of early modern printed (sales) catalogues. ${ }^{8}$ Writing

5 C. Roth and A.M. Habermann, 'Book trade', in F. Skolnik, etc. (eds.) Encyclopedia Judaica (henceforth: $E J$ ), 4 (Detroit: Macmillan Reference USA, 2007), pp. 77-78; M.H. Schmelzer, 'Bibliophiles', EJ, 3, pp. 681-683.

6 Roth and Habermann, 'Book trade'.

7 For example see A. Marx, Studies in Jewish history and booklore (New York: The Jewish Theological Seminary, 1944), pp. 198-237.

8 To name a few: Isaiah Sonne, 'Book lists through three centuries', Studies in bibliography and booklore, 1 (1953), pp. 55-76; Nehemia Allony, 'A book list from the twelfth century', Studies in bibliography and booklore, 6 (1964), pp. 174-16o [Hebrew]; Cecil Roth, Studies in books and booklore: essays in Jewish bibliography and allied subjects (Farnborough, Eng.: Gregg International Publishers, 1972), esp. pp. 155-164; Robert Bonfil, The rabbinate in Italy in the Renaissance (Jerusalem: Magnes Press, 1979) [Hebrew]; Robert Cohen, Jews in another environment: Surinam in the second half of the eighteenth century (Leiden: Brill, 1991) esp. pp. 106123; Sifra Baruchson, Book and readers (Ramat Gan: Bar-Ilan University Press, 1993) [Hebrew]; Daniel M. Swetschinski, Reluctant cosmopolitans. The Portuguese Jews of seventeenth-century Amsterdam (Oxford and Portland, OR: Littman Library of Jewish Civilization, 2004), pp. 289316; M.H. Schmelzer, Studies in Jewish bibliography and medieval Hebrew poetry: collected 
about these kind of sources in the context of Jewish studies, the terms 'Jewish' and 'Hebrew' are often also used interchangeably. For example, when we talk about 'the first Hebrew catalogue', what does the 'Hebrew' emphasise? It is the fact that the catalogue itself is printed in the Hebrew language, or that the catalogue contains Hebrew books? How should we understand and interpret this difference between Jewish and Hebrew? It might of course be significant that a catalogue itself is printed in Hebrew. However, when studying Jewish booklore, the object of study should not be limited to Hebrew material only, but rather include all books that belonged to Jewish owners. Indeed, printed sales catalogues of libraries of Jewish owners have different forms and types. They contain books in many different languages and on many different subjects. They range from catalogues entirely in the Hebrew language with mostly books on Jewish subjects, to catalogues that hardly contain evidence that they concern a 'Jewish' collection of books. Some list private collections that would be auctioned, while others indicate that the books belonged to the stock of a bookseller, printer or publisher. In Hebrew, the word mekhira is consistently used on title-pages to indicate the sale of the books; however, in most cases it seems that this sale was held in the form of an auction.

\section{Booksellers, Printers and Publishers}

Before coming to the central focus of this article, I discuss a few sales catalogues of printers and publishers in order to describe the differences between these catalogues and sales catalogues of private libraries, and to understand better the Jewish book trade and world of printing. Even though many stock catalogues of booksellers and printers had been published in the Dutch Republic in the first half of the seventeenth century, it took some time before the first one was published by a Jewish bookseller. Scholars often assumed that

essays (New York: The Jewish Theological Seminary, 20o6), esp. pp. 83-96; Joseph Hacker, 'Jewish book owners and their libraries in the Iberian Peninsula, fourteenth - fifteenth centuries', in Javier del Barco (ed.), The late medieval Hebrew book in the western Mediterranean: Hebrew manuscripts and incunabula in context (Leiden: Brill, 2015), pp. 70-104. Case-studies on Jewish libraries in the Dutch Republic: I. Maarsen, 'Een Haagsche boekcatalogus uit de achttiende eeuw', Ha'amoed (1933), pp. 5-6; Shlomo Berger, 'Codices gentium: rabbi Isaac Aboab's collection of classical literature', Studia Rosenthaliana, 29 (1995), pp. 5-13; Yosef Kaplan, 'The libraries of three Sephardi rabbis in early modern western Europe', in Yosef Kaplan and Moshe Sluhovsky (eds.), Libraries and book collections (Jerusalem: The Zalman Center, 2006), pp. 225-26o [Hebrew]; Harm den Boer and Jorge Ledo (eds.), Moria de Erasmo Roterodamo. a critical edition of the early modern Spanish translation of Erasmus's encomium moriae (Leiden: Brill, 2014), esp. pp. 1-47. 
Solomon ben Joseph Proops (d. 1734) was the first to publish a sales catalogue of Hebrew books, called Appiryon Shelomo (1730). ${ }^{9}$ In fact, however, several others had already been printed in the seventeenth century.

The first known catalogue of books for sale by a Jewish printer and bookseller appears to be published by Menasseh ben Israel (1604-1657) in 1648.10 This list of books, compiled in Latin, is divided into two parts: 28 books printed by himself -15 in Hebrew and 13 in Spanish - and $5^{26}$ other books. ${ }^{11}$ Considering the Latin headings and notes, and the Gregorian notation of the years, it was probably aimed at a non-Jewish, scholarly public. It is also interesting that the catalogue is arranged according to subject, probably to help the non-Jewish audience. Historians Leo Fuks and Renate Fuks-Mansfeld wonder whether the auction catalogue by Hendrick Laurensz from 1643 and his stock catalogue from 1647 were used by Menasseh ben Israel as an example. ${ }^{12}$ However, before 1648 dozens of stock catalogues had already been printed in the Dutch Republic. ${ }^{13}$ So this catalogue is actually not that different from its peers, except for being the first one with books on sale by a Jewish bookseller and printer. Another catalogue of Menasseh ben Israel's business does seem to be aimed at a Portuguese Jewish public, given the Portuguese language and the Jewish calendar used to denote the year of publication. This list from 1652 was prepared by his second son Samuel ben Menasseh Soeiro and contains 39 titles in Hebrew, and 26 titles in Spanish and Portuguese, all published in his printing shop. ${ }^{14}$ Particularly striking are the recorded prices of the books; according to the title, Samuel added them so that everyone could know the books' value.

Both lists of books show that Menasseh ben Israel was not only a printer and a publisher, but also a bookseller. In the Jewish book trade of Amsterdam, printers and publishers were almost always also active as booksellers; not only

9 G. Zilberberg and J. Breger, 'Hebrew printing', EJ, 16, pp. 529-540; Roth and Habermann, 'Book trade'.

10 Menasseh ben Israel 1648 , see appendix no. 52. On this catalogue see L. Fuks and R.G. Fuks-Mansfeld, 'Menasseh ben Israel as a bookseller in the light of new data', Quaerendo, 11 (1981), pp. 34-45.

11 Most numbers of books mentioned in this article are based on the numbers of lots within the catalogues. In reality the number of books may be slightly higher, since the numbering can be inconsistent and several books can be listed under one lot.

12 Fuks and Fuks-Mansfeld, 'Menasseh ben Israel as a bookseller', pp. 37-38.

13 A quick search in the BSCO database results in 66 stock catalogues printed in the period 1599-1647 in the Dutch Republic, of which 35 in Amsterdam; at least seven list Hebrew books.

14 Samuel ben Menasseh Soeiro 1652, see appendix no. 53. On this catalogue see A. Yaari, Studies in Hebrew Booklore (Jerusalem: Mossad Harav Kook, 1958), pp. 430-444 [Hebrew]; Fuks and Fuks-Mansfeld, 'Menasseh ben Israel as a bookseller', pp. 38-39. 
did they sell their own printed or published books, but also those of others. ${ }^{15}$ Book sales were in fact an important source of income for Jewish printers and publishers. ${ }^{16}$ Nevertheless, when Menasseh applied in 1648 for a license to open a bookshop this was refused; from 1632 onwards Jews in Amsterdam were not allowed to sell goods in official shops. ${ }^{17}$ Although the municipal authorities of Amsterdam did not authorise Jews to open bookstores, it seems, however, that they did allow the sale of books. Historians Shlomo Berger and Renate Fuks-Mansfeld both give seventeenth and eighteenth-century examples of Jewish printers and publishers who used locations to sell their books that were widely known among book buyers. ${ }^{18}$ For instance, during the first decades of the eighteenth century, Solomon Proops advertised in his books that all sorts of works, both old and new, could be bought in his house. ${ }^{19}$ According to Berger it is evident that such a shop was not an outlet of the family's printing products only. For that reason their printing house also served as some kind of a bookshop. However, was this indeed happening unofficially? While Jews were not allowed to work in professions that were organised in guilds, exceptions were made for Jewish book printers, surgeons and brokers. ${ }^{20}$ In March 1661 the Amsterdam printer Joseph Athias was the first Jew to be admitted to the booksellers' and printers' guild. In the following years several Jewish printers became members, such as David de Castro Tartas and members of the Proops family; some of them are listed in the registers as a 'boekverkoper' (bookseller). ${ }^{21}$ Can we assume that, while Jews in Amsterdam were officially not allowed to open a shop, in practice this rule did not apply to the Jewish

15 The use of the terms 'boekverkoper' (bookseller), 'boekdrukker' (printer), and 'uitgever' (publisher) is often ambiguous. The title-pages of printed books, advertisements and archival material show that these terms were used interchangeably in the early modern Dutch Republic.

16 Shlomo Berger, 'Agents of the book and their titles in Amsterdam Yiddish book industry 1650-180o', in Avriel Bar-Levav, etc. (eds.), Paths to modernity. A tribute to Yosef Kaplan (Jerusalem: Merkaz Zalman Shazar, 2018) [Hebrew].

17 R.G. Fuks-Mansfeld, 'The Hebrew book trade in Amsterdam in the seventeenth century', in C. Berkvens-Stevelinck etc. (eds.), Le magasin de l'univers. The Dutch Republic as the centre of the European book trade (Leiden: Brill, 1991), pp. 155-168, esp. p. 162.

18 Fuks-Mansfeld, 'The Hebrew book trade'; Fuks and Fuks-Mansfeld, 'Menasseh ben Israel as a bookseller'; Shlomo Berger, Producing redemption in Amsterdam: early modern Yiddish books in paratextual perspective (Leiden: Brill, 2013).

19 Shlomo Berger, 'Selling books in eighteenth-century Amsterdam. A Yiddish sale advertisement from circa 176o', Zutot, 5 (2008), pp. 129-134, esp. p. 131.

$20 \quad$ Fuks-Mansfeld, 'The Hebrew book trade', p. 162.

21 I.H. van Eeghen, De Amsterdamse boekhandel 1680-1725 (Amsterdam: N. Israel, 1978), vol. v, pp. 336 (Athias), 348 (Proops). 
members of the booksellers' guild? It seems that, although in theory certain laws existed, in reality practices could vary.

It took several years for other catalogues of Jewish booksellers and printers to appear. In this context a catalogue from 1688 listing the stock of Joseph Athias should be mentioned, although it was not published by Athias himself. ${ }^{22} \mathrm{~A}$ broadsheet with 25 books listed in the Dutch language contains the remainder of the Hebrew books from Athias' stock, that would be auctioned in the house of bookseller Henricus Wetstein. Athias himself was not involved in this sale, because he had given these books already in 1672 to the merchant Christoffel van Gangelt, as a deposit for unpaid debts. ${ }^{23}$

In 1704, the Portuguese Jewish bookseller and printer Isaac ben Abraham Cohen de Lara attached a small catalogue of the books he had for sale to his Calendario Judayco. It lists about one hundred 'libros Espannoles y Portuguezes Judaycos, de Theologia.' ${ }^{24}$ Harm den Boer, a scholar of Spanish literature, also found a catalogue included in Cohen de Lara's practical guide for visitors of Amsterdam titled Guía para passageros that was printed in the same year. ${ }^{25}$ This is a 21-page list of miscellaneous Spanish and Portuguese works, in contrast to the catalogue in the Calendario Judayco that consists only of 5 pages with primarily theological books. In 1724 another Amsterdam Portuguese Jewish publisher, Isaac Fundam, printed a catalogue with books and manuscripts in Spanish and Portuguese. ${ }^{26}$

The above-mentioned sales catalogues are all of Portuguese Jewish booksellers and printers. Given that three of these catalogues were published in the Portuguese language, they must have been aimed at the Portuguese Jewish community. The above-mentioned Ashkenazi printer Solomon Proops set up his own Hebrew press in 1704, establishing the well-known Proops family publishing business in a central position in the Amsterdam Jewish book industry that it would occupy for almost two centuries. It seems that only in 1730 did he follow the example of his Sephardi colleagues, when he printed a sales catalogue under the name Appiryon Shelomo. However, as mentioned above, Proops had already been advertising his books for some years. We may

\footnotetext{
22 Anonymous 1688, see appendix no. 54.

23 I.H. van Eeghen, 'Een veiling van boeken van Athias in 1688', Studia Rosenthaliana, 2 (1968), pp. 30-41.

24 Cohen de Lara 1704, see appendix no. 55.

25 Cohen de Lara 1704, see appendix no. 56. See Den Boer and Ledo, Moria de Erasmo Roterodamo, p. 40.

26 Fundam 1724, see appendix no. 57. In Bsco another catalogue from 1720 is listed that might have been printed by Isaac Fundam. However, the (sole) copy is lost and I have not found any other references to this catalogue that could confirm this assumption.
} 
therefore assume that more examples of sales catalogues must have existed that are no longer extant. Unfortunately, since no copy of Appiryon Shelomo has been preserved, we lack information about the style and language of the catalogue, and the number and kind of books listed. ${ }^{27}$ The publishing business of the Proops family not only printed, published and sold its own books, it was also highly involved in the printing and publishing of catalogues of private library collections, and their sales.

The sales catalogues of primarily Portuguese Jewish booksellers and printers discussed here list the books sold in their printing houses, which seemed to have been used also as their bookshop, whether this was officially allowed or not. It appears that practices within the book trade and printing business of the Jewish communities in the Dutch Republic took place in a legally grey area. As I will also demonstrate, it is to some extent unclear in which role printers, publishers or booksellers were involved in the production of a catalogue or the sale of a collection.

\section{Private Library Sales: A Quantitative Overview}

Studying private library catalogues can give us an idea of what an early modern library looked like, who the owners were and what reading interests they had. Private library catalogues were often, but not always, compiled after the owner of a book collection passed away. In Amsterdam, though not in The Hague or Leiden, it was forbidden by the booksellers' guild to auction books belonging to a living citizen..$^{28} \mathrm{~A}$ sales catalogue represents someone's collection at a specific moment in time. Its aim was not to give a complete overview of a private library, but to prepare the collection for the sale..$^{29}$ Before an auction took place, Amsterdam booksellers had to present a catalogue to the city wardens and they had to pay five gulden to gain permission to hold the auction. In

27 Proops 1730, see appendix no. 58. For references to this catalogue see for example 'Proops', EJ, 16, 562-563; Heller, 'The Hebrew book trade', p. 245; Shlomo Shunami, Bibliography of Jewish bibliographies (Jerusalem: Magnes Press, 1975), no. 2907.

28 H. van Goinga, 'Books on the move. Public book auctions in the Dutch Republic 17111805 mainly in Amsterdam, Groningen, The Hague and Leiden', Quaerendo, 35 (2005), pp. $65^{-95}$ esp. p. 75 .

29 For the problems and possibilities in using printed catalogues of private libraries as a source for the study book trade, book ownership, and readership see Helwi Blom, Rindert Jagersma, and Juliette Reboul, 'Printed private library catalogues as a source for the history of reading', in Mary Hammond (ed.), The Edinburgh History of Reading (Edinburgh: Edinburgh University Press, 2020). 
The Hague booksellers also had to request permission to hold a book auction. ${ }^{30}$ The almanacs of the guilds have partly been preserved; together with newspaper advertisements they sometimes add information on sales that took place, regardless of whether a catalogue has been preserved or not. The larger, often non-Hebrew catalogues of primarily Portuguese Jews were advertised in the most important regional Dutch newspapers. ${ }^{31}$

In theory all book auctions were recorded in the almanacs of the Amsterdam booksellers' guild. One of the reasons for registering the auctions was to administrate the auction fee: once the bookseller paid the fee, a line was drawn through the dates and names. This was also to prevent more than one auction being held on the same day. ${ }^{32}$ For example, an entry from 10 and 11 November 1772 reveals that an auction by Jacobus Benedictus, alias bookseller Kosman ben Joseph Baruch, was held on the same days as an auction by his colleague, César Noel Guerin, but with the consent of the latter party. ${ }^{33}$ Probably this was agreed upon, because the sale of the aforementioned concerned solely Hebrew books. Accordingly we can assume that catalogues without details about the owner or the bookseller, but with a date that fits the records of the guild, refer to the same event. A search of Jewish names in the Bibliopolis database, which contains data from different sources regarding auctions and catalogues, such as records from the guild almanacs and newspaper advertisements, produces the following results. ${ }^{34}$ At least 87 auctions were held in Amsterdam, The Hague and Rotterdam that involved Jewish owners or booksellers, the first being in 1693 and the last in $1811 .^{35}$ Of all the auctions recorded, only 22 match existing catalogues. In Figure 9.1 the number of extant catalogues and the registrations of auctions is shown. ${ }^{36}$ This discrepancy

$30 \quad$ Goinga, 'Books on the move', pp. 76, 73.

31 Advertisements in contemporary local Jewish newspapers (the few that are extant) will be the subject of further research, in order to find more details about the auctions of mainly Hebrew books.

32 Goinga, 'Books on the move', pp. $75^{-76}$.

33 University of Amsterdam, Bibliotheek van de Koninklijke Vereniging van het Boekenvak, Archief van het Amsterdams Boekverkopersgilde, Almanakken met optekening van verkopingen van boeken, drukkerijen, lettergieterijen etc. (henceforth: В КVB) B147 (10-11-1772). www.bibliopolis.nl. Also in book form: Bibliopolis. Geschiedenis van het gedrukte boek in Nederland, comp. M. van Delft and C. de Wolf (Zwolle: Waanders, 2003) (henceforth: Bibliopolis). Records from the вкVв for the period 1806-1811 are not recorded in Bibliopolis and have been added by myself.

35 This is based on a very preliminary search of typically Jewish and recurring names in Bibliopolis. I assume that more auctions were held during this period that involved Jewish owners or booksellers.

36 The beginning and the end of the period should be ignored because the registration started only in 1711 and ended in 1812 when the guild was discontinued. The decline after 1780 still has to be clarified. 


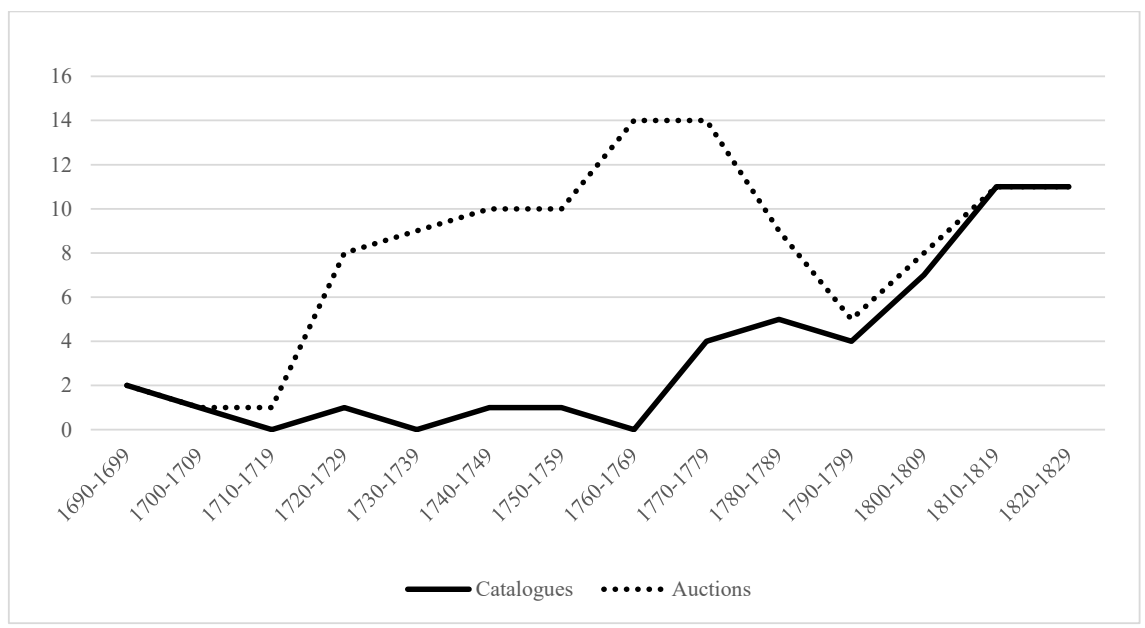

FIGURE 9.1 Number of auctions of Jewish-owned book collections in the Dutch Republic, $1690-1830$

corresponds with Rindert Jagersma's finding that only a small percentage 8.7\% for Amsterdam and $16.3 \%$ for the Dutch Republic as a whole - of the eighteenth-century catalogues have been preserved. ${ }^{37}$

Approximately half of the extant catalogues (22) match recorded auctions. So, what happened to the registrations of the other half of the catalogues? First of all, for specific years the almanacs of the Amsterdam booksellers' guild have gone missing, therefore a registration cannot be found of the auctions corresponding to catalogues from the period $1799-1801 .^{38}$ Secondly, the archives concerning book auctions in The Hague are quite incomplete. ${ }^{39}$ This leaves four catalogues which I assume should have been registered in the Amsterdam guild almanacs and for which I have not found a registration. This is in contrast to Van Goinga's research which concluded that, while sometimes the registration was done rather carelessly, no catalogues have surfaced whose auctions were not registered in the guild almanacs. ${ }^{40}$ Should we assume that my findings are different because they concern auctions involving Jewish booksellers? Like the confusion concerning the printing house as an unofficial place of sale,

$37 \quad$ See chapter four in this volume.

38 вкVв, B88-B184 cover for the years 1711-1719, 1721-1798, 1802-1812; the years 1720, 17991801 are missing.

39 Goinga, 'Books on the move', pp. 73-74.

$40 \quad$ Ibid., p. 76. 
this may be another example of a legally grey area in which Jewish booksellers and printers operated.

Even though the survival rate is low, about 3,200 private library catalogues are listed in the вsco database for the period 1600-1800. Of this impressive number, seventeen were identified by the compilers of the database as comprising a Jewish collection, three of which are labelled with a question mark. ${ }^{41}$ For this period, I can add another six Jewish-owned sales catalogues that are not listed in Bsco. ${ }^{42}$ Furthermore, for the nineteenth century up to 1830 I included 28 sales catalogues of Jewish-owned private libraries. Of these, eighteen were sold anonymously, meaning without specifying on the title-page to whom the collection belonged. Whether they are indeed of private libraries, or whether they might be booksellers' catalogues, will be discussed below.

Compared to the total number of catalogues printed in the Dutch Republic, these numbers are rather meagre. However, when placing the Dutch Jewish-owned catalogues in a European context, a different picture emerges. In his Bibliography of Jewish bibliographies, librarian and bibliographer Shlomo Shunami listed all private library sales catalogues of which the collectors are known. ${ }^{43}$ I used his book from 1975, combined with my own findings, to compare the situation before 1900 in the Dutch Republic to other countries. ${ }^{44}$ As can be seen in figure 2, this reveals the extraordinary place of the Dutch Republic in an European context.

41 This concerns the following catalogues listed in BSCO: Ludovicus Nonnius 1671, Mosis Betoule 1695, and Anonymous 1766. The second catalogue was not a Jewish collection, since Mosis Betoule was a French minister; see the advertisement in the Oprechte Haarlemse Courant of 11 June 1695 . Since I am not able to determine whether the other two were of Jewish owners, I did not add them to my appendix. Otto Lankhorst informed me that it was Henk de Kooker, one of the founders of вsco, who described all the catalogues listed in Bsco. Based on his own criteria he determined whether a collection belonged to a Jewish owner.

42 Anonymous 1747, see appendix no. 27; Meza 1743, see appendix no. 7; Anonymous 1758, see appendix no. 28; Anonymous 1772, see appendix no. 29; Anonymous 1784, see appendix no. 32; and Meldola 180o, see appendix no. 16. I found three of these catalogues in the British Library (London) and the Rijksmuseum (Amsterdam), even though these institutions are listed in BSCO as contributing libraries and archives.

43 Shunami, Bibliography of Jewish bibliographies, pp. $3^{8-76 .}$

44 I added six named catalogues that are not listed in Shunami: Haro 1637, see appendix no. 1; Andrade 1701, see appendix no. 5; Lopes Suasso 1773, see appendix no. 8; Senior 1782, see appendix no. 9; Pinto 1785, see appendix no. 10; and Löwenstam 1816, see appendix no. 22. 


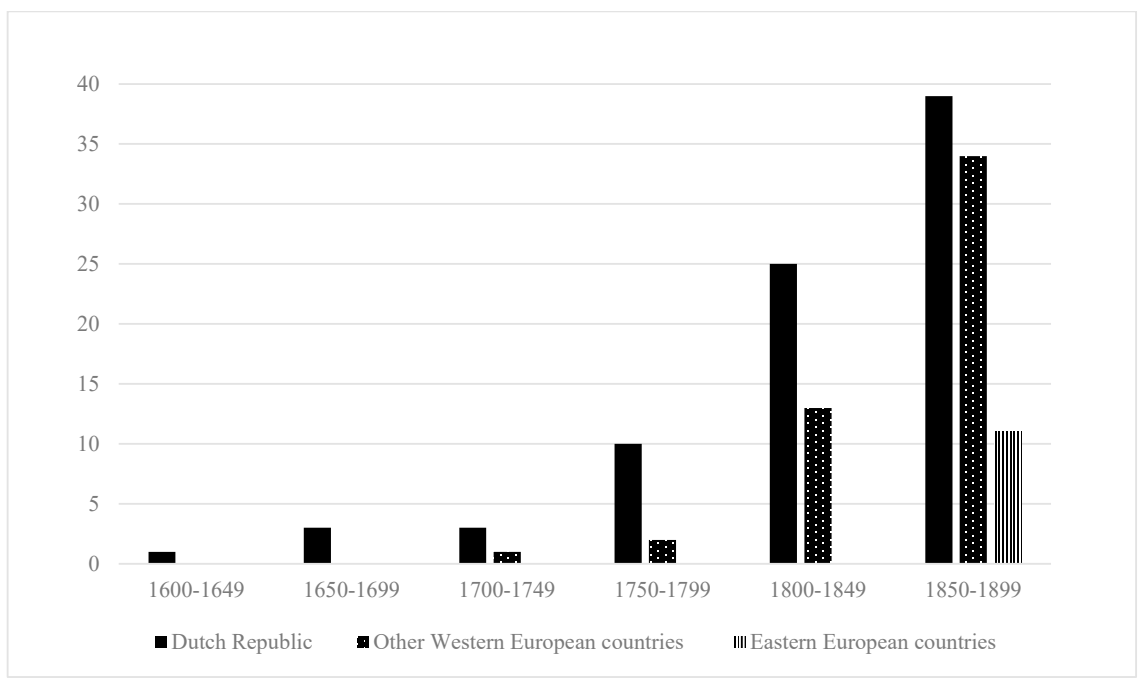

FIGURE 9.2 Number of catalogues of Jewish-owned private libraries printed in European countries before 1900

\section{The First Catalogues of Jewish-Owned Collections}

In previous scholarship, the earliest known 'printed sale catalogues of private Hebrew libraries' are always cited as the collections of Moses Raphael d'Aguilar, Isaac Aboab da Fonseca, and Samuel Abas. ${ }^{45}$ This phrase emphasises the Hebrew content of the library, but, as we have seen, Jews in the Dutch Republic did not only sell or own Hebrew books. Therefore, catalogues with a non-Hebrew content, as well as catalogues published in languages other than Hebrew, should be included. In this context, the first printed sales catalogue of a book collection of a Jewish owner might have been that of David de Haro, a Portuguese Jewish physician living in Amsterdam. The catalogue from 1637 of his library, hardly ever mentioned in studies on Hebrew bibliography or Jewish book history, was prepared in Latin. Besides a few Hebrew books, it contains mostly philosophical and medical books; especially the ones written by Iberian doctors are noteworthy. ${ }^{46}$

45 Schmelzer, 'Bibliophiles'.

46 Haro 1637, see appendix no. 1. On De Haro and this catalogue see Ian MacLean, Learning and the market place. Essays in the history of the early modern book (Leiden: Brill, 20o9), p. 394; P.I. Morrish, 'A collection of seventeenth-century book sale catalogues', Quaerendo, 1 (1971), p. 45, no. 31 . 
In 1680, a 48-page list of books was prepared to sell the collection of Moses Raphael d'Aguilar (d. 1679). ${ }^{47}$ This is the earliest known sales catalogue we know of that was printed in the Hebrew language. Unfortunately, at the moment there is no extant copy traceable; according to Bsco the catalogue of d'Aguilar should be in the Jewish Theological Seminary (JTs) in New York, but it is not recorded there. ${ }^{48}$ Two other early Jewish private library catalogues date from 1693, and record the collections of two Sephardi rabbis, Samuel ben Isaac Abas and Isaac Aboab da Fonseca. ${ }^{49}$ Abas' collection of 1,187 books was published and sold by Daniel van den Dalen in his bookshop on 3 March. ${ }^{50}$ The title-page starts with a Hebrew text followed by a Latin translation. All 236 Hebrew books are correspondingly listed in the catalogue with a Latin explanation in the column next to the Hebrew title. The books are categorised according to language, and subsequently according to format.

After the Hebrew section, a sheet (p. 11) is left mostly blank and the catalogue continues on a new page with the heading 'Catalogus librorum'. This emphasises the distinction between the two sections, since what follows are approximately 950 books in Latin, Spanish, Portuguese, Italian and French with non-Jewish subjects such as classical literature, medicine and history. In the advertisement for the auction this is also underlined by designating this part as the appendix. ${ }^{51}$

The catalogue listing the library of the renowned Amsterdam rabbi Isaac Aboab da Fonseca has a comparable layout to that of Abas: with Latin translations of the Hebrew title-page and the Hebrew books, and a similar categorisation. This catalogue was printed a few months later, in July 1693, by the Jewish printer David de Castro Tartas, and distributed and sold by Abraham Wolfgang. ${ }^{2} 2$

47 Aguilar 168o, see appendix no. 2. For references to this catalogue see Shunami, Bibliography of Jewish bibliographies, no. 212; Heller, 'The Hebrew book trade', pp. 254-255.

48 Rabbi Jerry Schwarzbard, librarian for special collections at JTS, and Sharon Mintz, curator of Jewish art at JTS, were so kind to check the JTS catalogue for me, but could not find any record of the collection of d'Aguilar. Unfortunately a search within the rare books department of JTS can currently not be carried out, because of a rebuilding project.

49 On these collections and rabbis see Kaplan, 'The libraries of three Sephardi rabbis'. For Abas see also Harm den Boer and Pier Mattia Tommasino, 'Reading the Quran in the 17th-century Sephardi community of Amsterdam', Al-Qanțara, 35 (2014), pp. 461-491; M. Studemund-Halévy, 'Codices Gentium. Semuel de Isaac Abas, Coleccionista de Libros Hamburgués' in J. Contreras and B. García García (eds.), Familia, religión y negocio. El sefardismo en las relaciones entre el mundo ibérico y los Países Bajos en la Edad Moderna (Madrid: Fundación Carlos de Amberes-Ministerio de Asuntos Exteriores, 2003), pp. 287-319.

50 Abas 1693, see appendix no. 3.

$5^{1}$ Oprechte Haarlemse Courant, 14-02-1693.

$5^{2} \quad$ Aboab da Fonseca 1693, see appendix no. 4. 
The auction of circa 560 books would take place in the house of the deceased rabbi. Besides 373 Hebrew items, Aboab da Fonseca owned eighteen Hebrew manuscripts. These are followed by 49 books in Spanish and Portuguese and four Latin books. The catalogue also has an appendix full of classical literature, with 114 books in Latin, Greek and Spanish. While large appendixes often do not belong to the main collection, I would follow Shlomo Berger's argument that, in this case, the books listed in the appendix also belonged to Aboab da Fonseca's collection. ${ }^{53}$ Similarly to the catalogue of Abas, the new section here titled as an appendix - marks a clear division between the different content of the two parts: while the main section consists primarily of Hebrew books and books on Judaism, the appendix lists books on non-Jewish subjects, mostly in Latin and Greek. This might have been a commercial decision to generate more attention for these non-Jewish books. Given the Latin title-pages and headings, and Latin translations of the Hebrew books in both catalogues, they were probably aimed at a non-Jewish, scholarly public. The advertisements for both auctions in the Oprechte Haarlemse Courant also point to this. ${ }^{54}$

\section{Non-Hebrew Catalogues of Jewish-Owned Collections}

Most of the Jewish catalogues before the end of the eighteenth century list collections belonging to owners with a Portuguese Jewish background. During this period we can discern a tendency (Figure 9.3) toward catalogues that were published entirely in either Latin, French or Dutch. Overall, these catalogues are slightly larger than the later printed Hebrew ones. Before examining the latter in the following section, I discuss here the non-Hebrew private library sales catalogues belonging to Jewish owners.

In April 1701, the library of rabbi and physician Isaac d'Andrade Velosinos (1657-c. 1700), was sold in The Hague by bookseller Abraham de Hondt. ${ }^{55}$ While this is one of the largest Jewish-owned sales catalogues I have found so far, it is never mentioned in Jewish booklore. A possible reason for this might be that hardly anything is known about d'Andrade, except for this extensive list of books. The Latin catalogue, with a Dutch preface, was distributed in cities

53 Berger, 'Codices Gentium', p. 5, n. 4. For a counter argument see Kaplan, ‘The libraries of three Sephardi rabbis', pp. 232-233.

54 Oprechte Haarlemse Courant, 14-02-1693 (auction Abas) and 14-07-1693 (auction Aboab da Fonseca).

55 Andrade 1701, see appendix no. 5. Profession and the years of birth and death are provided according to Bsco. 


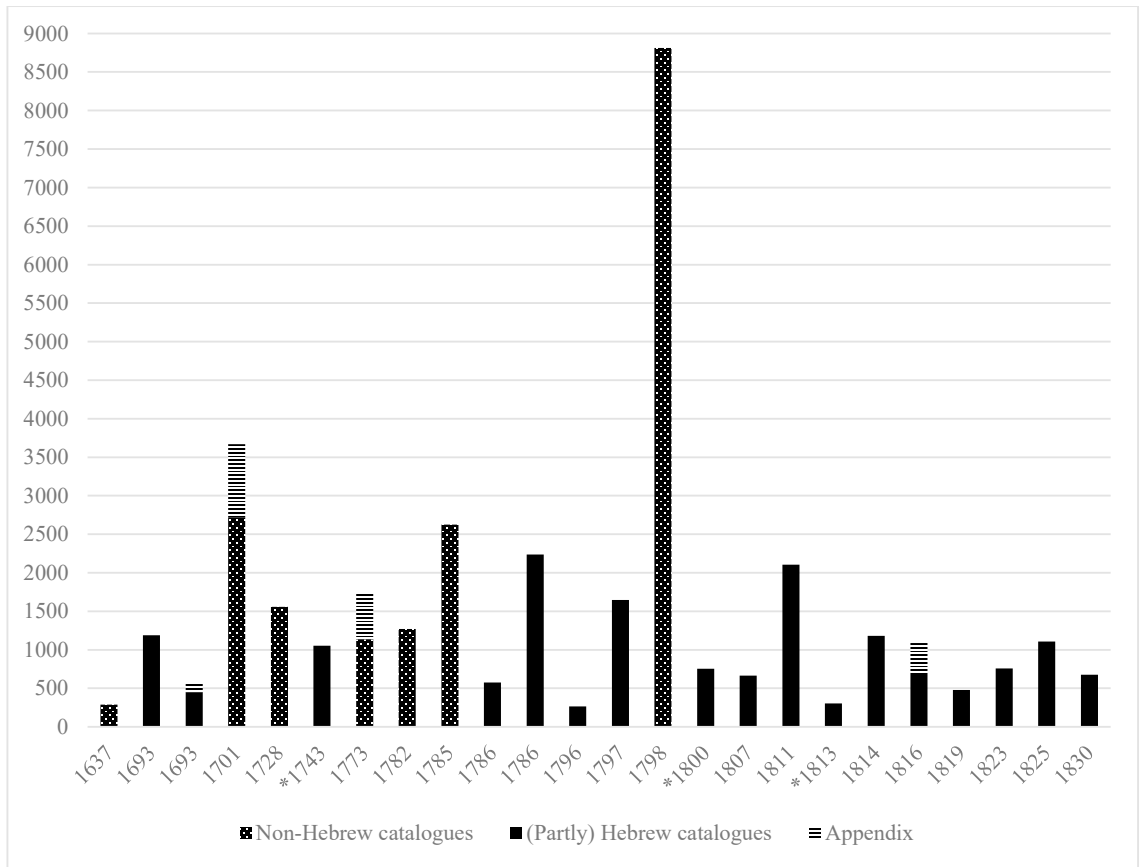

FIGURE 9.3 Number of lots in sales catalogues of named Jewish-owned private libraries printed in the Dutch Republic before 1830. *Numbers are acquired from Shunami's Bibliography of Jewish Bibliographies. It should be noted, however, that Shunami did not see these catalogues himself; he also does not indicate if a catalogue has an appendix.

throughout the Dutch Republic. ${ }^{56}$ It lists more than 2,70o books, excluding the circa 9oo books in the appendix. As the title-page states, the collection comprises theological, medical, historical and miscellaneous books in different languages, especially Hebrew, Latin, Italian, Spanish and French. The Hebrew books, however, are listed in Latin. Like most of the following catalogues, this catalogue categorised the books according to genre and format.

In 1728 a catalogue was published listing the collection of a renowned The Hague rabbi, David Nunes Torres (166o-1728). ${ }^{57}$ Like the previous catalogue, this one was published in Latin and it had a Dutch preface. Nunes Torres' very

56 Oprechte Haarlemse Courant, 12-04-1701, 14-04-1701, 19-04-1701 and 23-04-1701.

57 Nunes Torres 1728, see appendix no. 6. On Nunes Torres and his collection see Harm den Boer and Herman Prins Salomon, 'Haham David Nunes Torres (166o-1728), bezitter van het enig overgebleven exemplaar van Uriel da Costa's Exame das tradições fariseas', Studia Rosenthaliana, 28 (1994), pp. 10-98; Kaplan, 'The libraries of three Sephardi rabbis'; Yosef Kaplan, 'Spinoza in the library of an early modern Dutch Sephardic rabbi', in Camilla 
rich collection contains 1,556 books on theological, historical and miscellaneous subjects, in many languages: French, Latin, Spanish, Dutch, English, Italian and Portuguese. He owned the sole surviving copy of the denounced book Exame das tradições fariseas by Uriel da Costa. ${ }^{58}$ It is remarkable that this catalogue hardly contains Hebrew books, except for some Hebrew bibles. Given his work as both a publisher of rabbinic literature and a rabbi, he must have owned many Hebrew books. According to historian Yosef Kaplan 'the rabbi's Hebrew books ... were not meant to be sold' ${ }^{59}$ However, in the almanacs of the Amsterdam booksellers' guild I found the registration of another auction, with Nunes Torres' collection of Spanish and Hebrew books. This sale was held seven months later in Amsterdam. Moreover, it was not sold by the Christian bookseller Johannes Swart, who auctioned the first part of the collection, but by Amsterdam booksellers who knew the Jewish communities from within: Moses Frankfurt and Isaac Juda Leon Templo, in whose house the auction was held. ${ }^{60}$ Most likely the Hebrew and Spanish books, with mostly Jewish subjects, were excluded for commercial reasons. In this way the first catalogue could be aimed not only at a Portuguese Jewish public, but also at non-Jewish buyers. This case emphasises that a catalogue is not necessarily identical to someone's collection of books.

In 1773, the collection of doctor of law Manuel Lopes Suasso (1698-1773) son of a prominent Portuguese Jewish banking family - was published as a French catalogue and his 1,135 books (excluding an appendix of 588 books) were auctioned in The Hague by Nicolaas van Daalen. ${ }^{61}$ The auction was held in July 1773, about half a year after Lopes Suasso passed away. The collection was sold after the death of his wife, Judica Suasso Teixeira, in April of that same year. The auction included not only books, but also prints and portraits, atlases, sheet music, bookcases, and two harpsichords. The sale raised 3,275 gulden and 17 stuivers. ${ }^{62}$

In 1782, a 174-page catalogue was published with the belongings left by the well-known collector Juda de Benjamin Senior (d. 1782), 'beminnaar der

Hermanin and Luisa Simonutti (eds.), La centralità del dubbio. Un progetto di Antonio Rotondò (Florence: L.S. Olschki, 2011), pp. 639-662.

58 Den Boer and Salomon, 'Haham David Nunes Torres', pp. 10-11. Herman Prins Salomon, 'A copy of Uriel da Costa's "Exame das tradições fariseas" located in the Royal Library of Copenhagen', Studia Rosenthaliana, 24 (1990), pp. 153-168.

59 Kaplan, 'Spinoza in the library of an early modern Dutch Sephardic rabbi', p. 639.

6 в в Кв, B105 (о1-03-1729).

61 Lopes Suasso 1773, see appendix no. 8. Profession according to Bsco.

62 S.E. Veldhuijzen, 'Repertorium van Haagse Publieke Boekenveilingen 1745-1806' (not published), p. 561; в кVв, Luchtmans Archief, Auctie-rekeningen. 
kunsten en wetenschappen' (lover of the arts and sciences). His catalogue is written in Dutch and contains hundreds of (uncut) printed plays, many paintings and illustrations, sheet music and musical instruments, coins, and a total of 1,271 books. ${ }^{63}$ The catalogue of this collection was published and sold by bookseller and printer Jan Willem Smit. In 1785 , Smit auctioned an even larger collection of over 2,6oo books that belonged to the wealthy Amsterdam Portuguese Jewish merchant and collector Aaron de Joseph de Pinto (17101785) ${ }^{64}$ Similarly to the collection of Senior the many printed plays are announced on the title-page; these plays might indicate that both Senior and De Pinto were frequent visitors of the Dutch theatre. In addition, the presence of titles by Enlightenment authors that hardly appear in other Dutch collection show the modern character of De Pinto's collection. The categorisation of the books is mixed: most books are categorised according to genre, but the French and Spanish books are listed separately, according to their language. In this case De Pinto's collection of paintings, prints and 'liefhebberijen' (curiosities or collectables) was separated from the books and auctioned three weeks later. ${ }^{65} \mathrm{~A}$ final example is a French catalogue from 1798 listing the collection of Abraham Martins that was sold in The Hague by booksellers Isaac van Cleef, Bernardus Scheurleer and Jacques Detune. ${ }^{66}$ This enormous collection with 8,814 books on different subjects, such as medicine, philosophy, mathematics, grammar, poetry and history, also lists some Hebrew books, and Spanish and Portuguese manuscripts by Dutch Sephardi rabbis. ${ }^{67}$ The profit of the sale was an impressive 17,59 o gulden and 14 stuivers. ${ }^{68}$

These catalogues reflect the broad cultural horizon and intellectual interest of the elite of the Portuguese Jewish communities during this time. The collections express a strong affinity with the Iberian peninsula, as well as a great linguistic and thematic variety; many show a mix of Jewish tradition and contemporary European culture. Besides traditional biblical, liturgical and halachic works, we encounter books ranging from classical authors to modern Spanish literature to contemporary philosophical treatises. Consequently,

\footnotetext{
63 Senior 1782 , see appendix no. 9 .

64 Pinto 1785 , see appendix no. 10.

65 Oprechte Haarlemse Courant, 24-03-1785, p. 2.

66 Martins 1798, see appendix no. 15. According to Veldhuijzen, Repertorium van Haagse Publieke Boekenveilingen, p. 958. Martins was a Rotterdam notary and broker, according to Bsco a citizen from The Hague.

67 According to Shunami this collection contains 1,612 volumes; however, I counted 8,814 lots. Since Shunami did not see all the catalogues himself, we should take into account that he might have made more mistakes. 
many of these books could be of interest to a broad Dutch public. Similarly to the catalogues published in a combination of Latin and Hebrew belonging to the Portuguese Jewish rabbis discussed in the previous section, these catalogues were most likely aimed at an audience that, besides fellow Portuguese Jews, also included a non-Jewish public. This is indicated by the languages chosen for the publication, by the categorisation mostly according to genre, by the fact that these collections were published and sold by non-Jewish booksellers, and by the fact that these auctions were advertised in Dutch newspapers, such as the Oprechte Haarlemse Courant, the Leidsche Courant and the Amsterdamse Courant. Testifying to the existence of a diversified public, the two auctions - and probably two catalogues - with the collection of Nunes Torres serve as an example of how a collection could be split up, probably for commercial reasons.

\section{Hebrew Catalogues of Jewish-Owned Collections}

From the second half of the eighteenth century we see a new phenomenon: catalogues of Jewish-owned private libraries published entirely or mostly in the Hebrew language. Although most books listed are Hebrew and Yiddish works, the catalogues also record in Hebrew scripts works in other languages. Most of these catalogues were published anonymously. However, twelve catalogues, the first published in 1786 , the last in 1830 , have been preserved that do specify the name of the collector on the title-page. To these catalogues, we can add four that are listed in reference works, but cannot currently be located. ${ }^{6}$ A relatively early Hebrew catalogue was printed in 1743 in Amsterdam with the books of Solomon de Meza (d. 1742), alias Solomon Mendes Floris, who was a physician and rabbi of the Portuguese Jewish community of Amsterdam. It is striking that, while the larger non-Hebrew catalogues had owners with a Sephardi background, the majority of named Hebrew book lists from the end of the eighteenth and beginning of the nineteenth century are from Ashkenazi Jews. Before discussing the anonymous catalogues in the next section, I examine here some of the private library sales catalogues of Jewish owners whose names are highlighted on the title-pages.

69 Shunami, Bibliography ofJewish bibliographies, no. 337 (Solomon de Meza); no. 335 (David de Raphael Meldola); no. 354 (Manuel Osorio); and no. 339 (Loeb de Metz). The catalogue of Meldola is recorded in the inventory of Ets Haim-Livraria Montezinos (henceforth: EH) of Amsterdam as EH 34 B 42 (25), but is unfortunately missing. 
In 1786 two very different private library catalogues were auctioned within less than two months. One catalogue contains the collection of Saul Halevi (1712-1785), who was a respected scholar and hakham of the Ashkenazi community in The Hague. This small catalogue of 575 books is entirely printed in Hebrew. ${ }^{70}$ The larger list of the books of Solomon Cohen Samuelsz from Rotterdam, with 2,238 items, was printed by Jacob Proops and has two title-pages, the first in Dutch, followed by another in Hebrew. ${ }^{71}$ It is striking that the Dutch title-page provides more information than the Hebrew, which does not even state the name of the owner of the collection. The Dutch title-page also announces that the collection was to be sold by Jurianus van Mekeren and Johannes Nozeman for the widow of auctioneer Laurens Constant. Did the Jewish publisher and Christian booksellers assume that Jewish buyers would read the Dutch title-page first, and that this would entice Christian collectors of Hebrew and Jewish books to come to the sale? Except from the Dutch title-page, the entire catalogue is in Hebrew.

A collection that was also catalogued and published in Amsterdam by the Proops family, but sold in Rotterdam, was in the possession of Jacob Isaac Levi, alias Jacob Leeuwarden. ${ }^{72}$ The sale of his 1,647 books was held in April 1797. Exceptionally, the Bibliotheca Rosenthaliana holds an eighteenth-century manuscript catalogue of this collection, that was probably made before the printed sales catalogue. ${ }^{73}$ The same applies to the very small catalogue that was printed in 1796 in Amsterdam with the collection of Abraham ben Isaac Keizer. ${ }^{74}$ According to Fuks, Keizer was 'a well-to-do Amsterdam Jew ... who had a liking for beautiful manuscripts. ${ }^{75}$ Before this catalogue was printed, Keizer listed all his books in a beautifully arranged manuscript. ${ }^{76}$ The manuscripts provide the possibility to compare the original collection of books to the books listed in the printed sales catalogue. For example, the manuscript catalogue of Keizer's collection lists about sixty titles that are not recorded in the printed catalogue, while the printed catalogue lists about fifty works that do not appear in the manuscript. This discrepancy could indicate that in the

\footnotetext{
$70 \quad$ Halevi 1786, see appendix no. 11.

71 Cohen Salmuelsz 1786, see appendix no. 12.

72 Levi 1797 , see appendix no. 14.

73 University Library Amsterdam (henceforth: UBA), HS. ROs. 480; see also L. Fuks and R.G. Fuks-Mansfeld, Hebrew and Judaic Manuscripts in Amsterdam Public Collections, I (Leiden: Brill, 1973), no. 604.

$74 \quad$ Keizer 1796, see appendix no. 13.

75 Fuks and Fuks-Mansfeld, Hebrew and Judaic Manuscripts, I, no. 267.

76 UBA, HS. Ros. 261; see also Fuks and Fuks-Mansfeld, Hebrew and Judaic Manuscripts I, no. 6 o1.
} 
printed catalogue, on the one hand, books were left out on purpose, for example to be kept by family members. On the other hand, the books that are only listed in the printed catalogue might have been purchased in the period after finishing the manuscript, or they were possibly added by members of the family or the bookseller.

Libraries collected by Ashkenazi Jews and auctioned in Amsterdam included the 478 books owned by merchant Moses Leman Jacobs (176o-1819), alias Moses Lieme Wing, sold in October 1819 by Yohanan Levi Rofe and his son Benjamin. The title-page of his collection is reminiscent of the catalogues of the first Sephardi rabbis. While the title-pages of their catalogues provided a Latin translation of the Hebrew text, the lower half of this one is in Dutch. ${ }^{77}$ In 1814, the rich library collected by the famous poet and scholar Solomon ben Joel Dubno (1738-1813), who took his name from his birthplace in the Ukraine, was auctioned in Amsterdam. ${ }^{78}$ Dubno passed away in Amsterdam, after having lived there for the last two decades of his life. His large collection contained over a thousand printed books, many of them rare, and more than one hundred manuscripts. Contemporary accounts tell us that Dubno had lived in Amsterdam in such poverty that he was forced to loan books from his collection to 'friends of Jewish literature' for small sums. ${ }^{79}$

In 1823, one of the few Hebrew catalogues listing the collection of a Portuguese Jewish owner was sold in Amsterdam. This comprised around $75^{\circ}$ books that had belonged to Daniel Cohen d'Azevedo (c. 1746-1822), hakham of the Portuguese Jewish community in Amsterdam. ${ }^{80}$ The catalogue of the Sephardi Solomon Jessurun (d. 1811) is interesting because it seems to consist of two catalogues, or at least two parts: one with a Dutch title-page and Dutch headings, and one entirely in Hebrew. ${ }^{81}$ While the categorisation in the Hebrew part is according to format and alphabet, the part with a Dutch title-page has a jumbled categorisation system of both language and genre. The latter part contains many theology, history and literary books in Spanish, Portuguese, French and Dutch, but also some in Italian, Latin and English. With this linguistic and thematic variety this part of the collection resembles the other non-Hebrew catalogues of the Sephardi elite. Remarkable in this collections are also the 250 rare Hebrew, Spanish and Portuguese manuscripts by, among others, Menasseh

77 Leman Jacobs 1819, see appendix no. 19.

78 Dubno 1814, see appendix no. 21. The Bibliotheca Rosenthaliana holds a manuscript inventory (UBA, HS. ROS. 469) from 1771 of Dubno's collection, see Fuks and Fuks-Mansfeld, Hebrew and Judaic Manuscripts I, no. 6 oo.

79 Marx, Studies in Jewish history and booklore, p. 221.

$80 \quad$ Cohen d'Azevedo 1823, see appendix no. 24.

81 Jessurun 1811, see appendix no. 18. 
ben Israel, Isaac Orobio de Castro and Saul Levi Morteira. The two catalogues were probably printed as separate catalogues for practical reasons - two different types of letters - and aimed at different potential buyers.

In total, of the twelve sales with mostly Hebrew books from the second half of the eighteenth and beginning of the nineteenth century, eight were held in Amsterdam, two in Rotterdam and two in The Hague. Most of these catalogues were actually printed in Amsterdam by two well-known publishing families. Except for a couple of catalogues belonging to Portuguese Jewish collectors, these Hebrew catalogues list collections belonging to Ashkenazi Jews. If we compare these catalogues (Figure 9.3) to the non-Hebrew catalogues of Portuguese Jewish owners, it appears that the numbers of books in these Ashkenazi Hebrew collections on the whole is smaller. Moreover, compared to the Portuguese Jewish-owned catalogues, these catalogues seem to reflect a more traditional character. In the collections of Ashkenazi owners Hebrew and Yiddish works on religious subjects, such as liturgy, ethics and law, seem most prominent. In addition, grammars and manuals are frequently listed. Furthermore, in contrast to the categorisation by subject, the Hebrew catalogues are arranged by format, and within each format by alphabet. These catalogues were printed to attract members of the Jewish communities to the auctions. A few of the catalogues with a Dutch title-page may have tried to attract a broader, non-Jewish public of buyers (although many Jews at the beginning of the nineteenth century most likely also read Dutch). Finally, what does this new phenomenon of Hebrew catalogues suggest? In a community where Hebrew and Yiddish were prevalent, it is not surprising that these catalogues are published in Hebrew and that books in these languages dominate. Moreover, as will be also emphasised below, the central position of the Jewish printers' families Proops and Levi Rofé might have given an impulse to produce and publish private library catalogues in the Hebrew language.

\section{Hebrew Catalogues of Anonymous Collections}

The anonymous catalogues from the end of the eighteenth and beginning of the nineteenth century, with a single exception, are part of the trend of increasing numbers of Hebrew catalogues during this period. To the Hebrew catalogues of named owners I can add 24 anonymous - but without a doubt Jewish-owned - catalogues that were published in the Hebrew language. All were printed for a special sale or auction that would be held over one or two days. However, since these catalogues lack the name of the owner, it is not always evident whether these anonymous sales catalogues might be of privately owned libraries. One catalogue with a particularly intriguing character 
is from 1747. It contrasts sharply with the rest, because it is very small - three pages listing about one hundred books - and does not have a title-page. ${ }^{82}$ While the heading states that the books listed in the catalogue would be sold on Thursday 25 Kislev 1747, it fails to announce a place of sale. So, how should one have understood where the sale would be held? To confuse matters further, no printer or bookseller is mentioned.

In the case of several other catalogues, it is unclear how the Proops family and others named on the title-pages were involved in the sale. While a catalogue from $175^{8}$ states that the books were to be sold in Amsterdam by the Proops brothers and broker Abraham Semah Aboab Isaac, the title-page of the catalogue from 1773 announces that the sale would take place in the house of bookseller Solomon Levi Maduro and would be held by Solomon Proops. A further catalogue from 1784 mentions that the books were to be sold by Joseph ben Jacob Proops. ${ }^{83}$ This information is not sufficient to determine whether these catalogues list the retail stock of the Proops family business or, in the case of the first catalogue from 1773, whether they concern the private collections of one of the men involved, or whether they participated in the sales of anonymous collections as third parties, in the role of printer, bookseller or a broker. ${ }^{84}$ Fortunately the Amsterdam guild almanacs can fill in some of these lacunae, since in all three instances they record that the books were auctioned by members of the Proops family, which presumably means they did not sell their own stock. ${ }^{85}$ The records from 1773 and 1784 provide us with the names of the actual owners of the collections: Jacob Abanacker for the first, and Jacob Norden for the latter. ${ }^{86}$ Accordingly I would argue that the book collection sold in 1758 must also have belonged to a private owner.

In this light and studying the layout, the texts on the title-pages, and the other people involved in the sales, it could be hypothesized that the rest of the anonymous catalogues are also of private collections. ${ }^{87}$ In some cases this

\footnotetext{
82 Anonymous 1747, see appendix no. 27.
}

83 The catalogues from $175^{8}$ and 1773 do not explicitly state by whom they were printed, while the one from 1784 does have the printer's mark of the Proops family on its title-page.

84 In BSCO the catalogue of 1773 is categorised as 'auction catalogue retail stock'; it is however not clear why. See also A.E. de Wilde, 'How to Understand 'al yede? Title Pages of Hebrew Private Library Catalogues Printed in the Dutch Republic during the Long 18th Century', Zutot, 17 (2020) pp. 74-82.

85 In the almanacs there is written 'door' or 'bij' (by) followed by the name of a bookseller, contrasting to 'van' (of) in cases of owners.

86 в кVв, B148 (29-о3-1773) and B159 (13-12-1784).

$87 \quad$ While I argue here that most of these anonymous catalogues were of privately owned library collections, in this phase of my research, I do not want to exclude the possibility that the books on sale in these catalogues belonged to the business of a Jewish bookseller or printer. Further research will be needed to confirm this. 
can be confirmed by the registration from the guild almanacs. For example, the anonymous catalogue of an auction that was held on 7 February 1810, can be linked to the sale of the books of a certain Arons. ${ }^{88}$ Another auction that I referred to earlier, was held on 10 and 11 November 1772 by Jacobus Benedictus, alias bookseller Kosman ben Joseph Baruch, and contained the books of Dr Van Emden. ${ }^{89}$ These dates correspond to the dates mentioned in one of the anonymous catalogues. While the title-page only stated that the books would be sold in the new 'wedding house' (where family feasts were held) of a certain Joseph Schwerin, this catalogue can now be linked to Dr Van Emden. In other cases, the records just mention the bookseller or auctioneer, and frequently there are no records left at all.

The owner of another anonymous catalogue can be identified on the basis of a handwritten note in a copy belonging to the heirs of the owner, which states that it concerns 'the Hebrew library of the late Mr. Simon Boas'.90 Boas was a member of the famous banking family that resided in The Hague. This catalogue with 481 books was printed in 1799 in Amsterdam by Yohanan Levi Rofe and his son Benjamin, while the sale was held in The Hague. ${ }^{91}$ In addition, an appendix has been preserved containing 268 books that were sold on the same day as the collection of Simon Boas. According to the compilers of BSCO the collection listed in the appendix may have belonged to one of Simon's brothers, Benjamin or Israel..$^{92}$

One anonymous sales catalogue from 1775 stands out because it was published in the Dutch language. ${ }^{93}$ Probably it did belong to a Jewish owner, given the Jewish books, the Jewish bookseller and broker involved in the sale, and the location of the sale in the Jewish quarter. Dutch and French books on different subjects make up about half of the collection (circa 250 books). Furthermore, the collection consists of Portuguese and Spanish books on mainly Jewish subjects, including several titles written by local Sephardi rabbis, that point toward a Portuguese Jewish owner. Two other anonymous catalogues from September 1802 and October 1812 most likely also belonged to Portuguese Jewish collectors. These catalogues stand out in particular because they have both a Hebrew part with Hebrew books, and a Dutch part with among others Spanish, Portuguese, French and Dutch books on both Jewish and non-Jewish

88 вкVв, B182 (о7-02-1810); Anonymous 1810, see appendix no. 39. The name start with Arons[...], but the last letters of the name are difficult to determine.

89 вКVв, B147 (10-11-1772).

9o Maarsen, 'Een Haagsche boekcatalogus uit de achttiende eeuw', p. 6.

91 Anonymous 1799, see appendix no. 33.

92 See entry of this catalogue in the вsco database.

93 Anonymous 1775, see appendix no. 31. 
subjects. ${ }^{94}$ As we have seen concerning the collection of Solomon Jessurun (1811), the two parts were probably printed separately for practical and economic motives; and in some cases these were later bound together.

\section{Title-Pages of Hebrew Catalogues of Jewish-Owned Collections}

The layout of the anonymous catalogues is largely similar to that of the named Hebrew catalogues from the end of the eighteenth century and the beginning of the nineteenth century. This uniform appearance may be because most of the private library catalogues from this period were printed in Amsterdam by two well-known publishing families: the members of the Proops family and the Van Embden family, represented by Yohanan Levi Rofe (1741-1826), alias Joachim van Embden, and his son Benjamin. ${ }^{95}$ In Figure 9.4 the dominant position of both printers' families can be discerned. ${ }^{96}$ Based on the extant catalogues, the number of catalogues printed by the Proops family is more

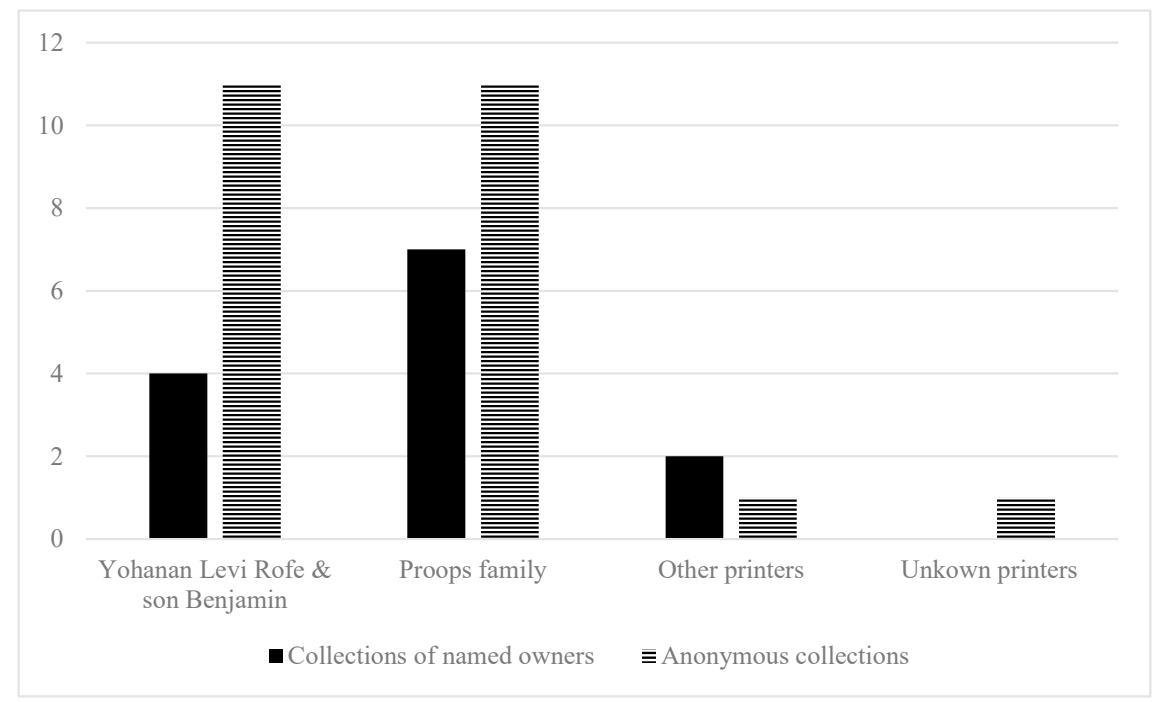

FIGURE 9.4 Number of Hebrew (private library) sales catalogues published by Jewish printers in the Dutch Republic, $1750-1830$

94 Anonymous 1812, see appendix no. 40; anonymous 1802, see appendix no. 37 .

95 After Yohanan Levi Rofe's death, the business continues as Van Embden \& co. See also Hindle S. Hes, 'The Van Embdens. A family of printers', Quaerendo, 11 (1981), pp. 46-52.

96 Although the catalogues from $175^{8}$ and 1773 do not explicitly note by whom they were printed, I assume that it was by the Proops family since their names clearly state on the title-pages. Accordingly, I added them as such to this figure. 
evenly spread over the period 1750-1830 than the number printed by Levi Rofe. Also, the Proops family business seems slightly stronger in the second half of the eighteenth century, while Levi Rofe leads in the first half of the nineteenth century. This picture is also reflected in the search for Jewish names in the Bibliopolis database I mentioned earlier; for the period 1710-1810, around forty percent of the auctions concerning Jewish owners or booksellers seem to be connected to the Proops family. These figures confirm the important place of both families in the Jewish and Hebrew book trade in the Dutch Republic. Equally, these printing businesses might have stimulated the publication of this kind of ephemera and the auctioning of private library collections for economic purposes.

The first catalogues published by the Proops family have a very unusual long quarto format. ${ }^{97}$ Two other catalogues from around this period - on which no printer or publisher is recorded - have the same format. ${ }^{98}$ Was this a fashion in printing in the Dutch Republic? Or were those two also printed by the Proops family business? In 1786 a change occurs within the printing press of the Proops family: while the catalogue of Solomon Cohen Samuelsz from July 1786 is already published as an octavo, like most of the catalogues in the following decades, the catalogue of Saul Halevi from August 1786 is still in a long quarto format.

The style and layout of Yohanan Levi Rofe's catalogues look similar to that of the catalogues printed by the Proops family, and to one catalogue printed by Jacob Belinfante. All catalogues start with the Hebrew words meaning: 'A list of important and precious books'. Hereafter some present an extensive list of the books' subjects, while others highlight two or three subjects. Interestingly, quite a few announce the sale of sifre torah (Torah scrolls) together with the aron ha-kodesh, an ark where one keeps the Torah scrolls. This indicates their use in the private sphere, contrary to the use of Torah scrolls exclusively in the synagogue..$^{99}$ All catalogues state the Hebrew date of the sale, and from the beginning of the nineteenth century in two thirds of the cases also the Gregorian date. Most title-pages announce the specific time and the place of the sale; in several cases this is stated in Yiddish.

The location of the sale could be in a public place, such as the Great Hall, in which public book auctions in The Hague were held, a Jewish 'wedding house', or the 'Kahal Kadosh', which is a general term for the Jewish community, thus

97 Anonymous 1758, see appendix no. 28; Anonymous 1773, see appendix no. 30; Anonymous 1784, see appendix no. 32; and Halevi 1786, see appendix no. 11.

98 Anonymous 1747, see appendix no. 27; and Anonymous 1772, see appendix no. 29.

99 Cf. Swetschinski, Reluctant cosmopolitans, p. 289. 


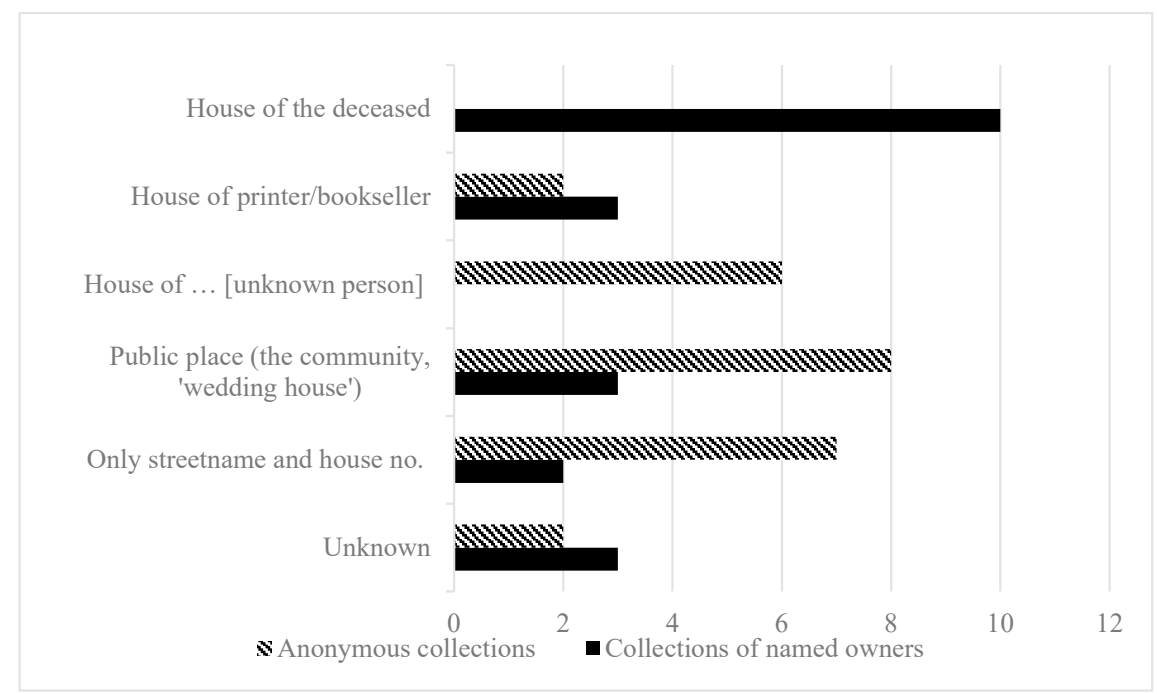

FIGURE 9.5 Auction venues as listed in Jewish-owned (private library) sales catalogues printed in the Dutch Republic before 1830

readers must have understood which exact place was meant. As is shown in Figure 9.5, most of the auctions of named Jewish owners - including the non-Hebrew catalogues - were held in the house of the deceased. There are quite a few anonymous collections that were sold at a specific address and others that state that the books would be 'sold in the house of' a certain person. A catalogue from 1772 mentions that the books were to be sold in the house of Joseph Schwerin; a catalogue from 1802 announces that the books were to be sold in the house of rabbi Aron IJzerloon; a catalogue from 1813 states that the books were to be sold in the house of rabbi Hirsch Goudstikker; in 1822 another book sale would take place in the house of Chaim Blitz and in 1826 the house of Joseph Richter. ${ }^{100}$ How were these persons, whose names do not reappear in other extant catalogues, related to the collections? Should we infer from the title-pages that they were the owners of the collections on sale? Other than the fact that the sale was in their house, there are no indications that they were selling part of their own collections. In addition, these persons were alive whereas most book auctions took place after a collector's death. As we have seen, the guild almanacs record that the books sold in 1772 in the house of

100 In order mentioned: Anonymous 1772, see appendix no. 29; Anonymous 1802, see appendix no. 36; Anonymous 1813, see appendix no. 41; Anonymous 1822, see appendix no. 45; and Anonymous 1826, see appendix no. 50. 
Joseph Schwerin belonged a certain Dr Van Emden. ${ }^{101}$ It therefore appears that these men might only have provided a venue to sell anonymous collections in their houses.

Another aspect mentioned on most of the title-pages is that the books could be viewed one or two days before the sale and that the catalogue could be obtained in the house of the printer. In most cases the printers of the catalogue as stated at the bottom of the title-page also functioned as the booksellers and auctioneers of the collection; they were the ones to ask permission from the guild. In several cases additional roles are mentioned on the title-pages, such as a broker or another bookseller who helped with the auction. An anonymous private library collection auctioned in February 1758 was sold by the Proops brothers and by Abraham Semah Aboab Isaacz from Alkmaar. ${ }^{102}$ The latter was listed as a Jewish broker ('Joodsche Makelaar') between 1742 and 1765 by the Amsterdam brokers guild. ${ }^{103}$ In the almanacs of the booksellers' guild he is mentioned no less than five times with other booksellers or brokers, and three times as the sole auctioneer. ${ }^{104}$ Also, in the 182 os clerk ('griffier') Tobi Boas was a frequently mentioned name, and appears four times on title-pages as the auctioneer. ${ }^{105}$

\section{Conclusion}

This overview of Dutch Jewish-owned book sales catalogues shows that the Dutch Republic was a flourishing centre for the Jewish book trade. Not only were numerous second-hand books coming from private libraries sold at auctions, but the practice of printing auction catalogues also became a business in itself. Amsterdam, with its lively intellectual environment, was the heart of Jewish printing; books were printed in a number of languages, such as Hebrew, Yiddish, Spanish and Portuguese - a multilingualism that also characterises

\footnotetext{
101 Anonymous 1772, see appendix no. 29.

102 Anonymous 1758 , see appendix no. 28.

103 Lyste dernaamen en woonplaatsen van de makelaars [...] derstadt Amsterdam (Amsterdam, 1765), p. 35 .

104 Abraham Semah Aboab Isaacz mentioned with other booksellers or brokers, see вкVв, B117 (1742-о3-12); вкVв, B118 (1743-о3-о6 and 1743-о6-25); вкVв, В131 (1756-о8-24); and в КVв 146 (1771-07-24). And mentioned as the sole auctioneer, see в КVв, B124 (1749-073о); вкVв, В125 (1750-12-3о); аnd вкVв, В132 (1757-о9-27).

105 Anonymous 1812, see appendix no. 40; Anonymous 1821, see appendix no. 44; Anonymous 1822, see appendix no. 45; Cohen d'Azevedo 1823, see appendix no. 24; and Liefmans 1825, see appendix no. 25 .
} 
the Jewish collections listed in the catalogues. Jewish book collectors and printers followed the Dutch trends in printing when cataloguing, publishing, and auctioning Jewish-owned private book collections; and adjusting the catalogues to their own needs, they were often printed in Hebrew. Just as the Dutch had started this practice, Jews in the Dutch Republic were forerunners in comparison to other European Jewish communities. In the Dutch (Jewish) book trade actors from various backgrounds were involved. Accordingly, encounters between Ashkenazi Jews, Sephardi Jews, and Christian booksellers were frequent in drawing up book sales catalogues and organising book auctions. These different groups were not only involved as business partners, but also as potential audiences. Accordingly, collections were split up and aimed at different publics in order to make the most profit.

The extant catalogues discussed here reveal the cultural and intellectual interests of the Jewish communities of the Dutch Republic. The collections belonging to Ashkenazi and Sephardi owners reflect the differences in their backgrounds, which was expressed in the choice of the language of the catalogues and the linguistic and thematic variety of the listed books. Until the second half of the eighteenth century, almost all catalogues printed were of collections belonging to prominent and highly educated collectors with a Sephardi background, such as rabbis, physicians or bankers. The catalogues of their collections reflect the broad interest of Portuguese Jews both in Jewish tradition, as well as their Iberian heritage, and contemporary European culture. Moreover, the fact that the catalogues were published in Latin, French or Dutch, or in some cases combined with Hebrew, should be understood in this context. Given the great linguistic variety of their collections and the small number of Hebrew books, it is not surprising that the catalogues were published in other languages than Hebrew. Furthermore, these rather large collections were published and the books auctioned by non-Jewish booksellers, and probably aimed first of all at a Christian public of buyers, besides other Portuguese Jews. Indeed, in cases where a Portuguese Jewish collector did own a large Hebrew book collection, it was catalogued and auctioned separately.

At the end of the eighteenth century we see a trend emerge of sales catalogues of Jewish-owned book collections printed entirely or partly in the Hebrew language. The majority of the named Hebrew catalogues are of collections belonging to Ashkenazi Jews. As the Hebrew and Yiddish language were dominant in the Ashkenazi communities, so too were the Hebrew and Yiddish works dominant in these rather small collections, in which traditional liturgical and halachic works are listed most frequently. Given the Hebrew language and Jewish subjects of the works, these catalogues were printed to attract 
to the auctions primarily buyers from within the Jewish communities, both Ashkenazi and Sephardi. The booksellers who produced the few catalogues with a Dutch title-page may have tried to reach a wider, non-Jewish audience. Not surprisingly, Jewish printers and booksellers published these Hebrew catalogues and led the auctions. In fact, we might assume that the domination of the market by the Proops printers' family and printer Yohanan Levi Rofe and his son Benjamin led to the flourishing of Hebrew catalogue publishing.

This overview is a first step toward treating Jewish-owned catalogues of the long eighteenth century as a comprehensive corpus, in the context of wider European practices of publishing private library sales catalogues. Distinguishing the various elements that I have discussed in this article may help to tackle the complexity of this corpus of Jewish-owned sales catalogues and the sometimes confusing practices of the book trade and printing business within the Jewish communities of the Dutch Republic. As I have shown, many fundamental questions concerning this corpus remain, and we are only beginning to get a view of its importance for the history of Jewish print culture in early modern and Enlightenment Europe.

\section{Appendix of Jewish-Owned Sales Catalogues Printed in the Dutch Republic until 1830}

A Private Library Sales Catalogues

1. David de Haro

Amsterdam: Jan Fredricksz Stam, 1637

Catalogus librorum ... D. David de Haro ... Amsteldami ... Martij M.DC.XXXVII

290 lots

Oxford, MC: 66 g. 7:12

2. Moses Raphael d'Aguilar

Amsterdam, 1680

רשימת ספרי ... ה"ר משה רפאל די אגוילאר הספרדי ...

[JTS?] BSCO; Shunami, no. 212

3. Samuel ben Isaac Abas

Amsterdam: Daniel van den Dalen, 1693

לוח ספרים ... שמואל אבץ ... לחדש השלישי הוא חדש מארסו שנת תק"ן... פה

אמשטירדאם ספרים....

Catalogus variorum ... librorum ... Samuel Abas ... [3] Mart. 1693 ... 1187 lots

State and University Library Hamburg, B Abbas; Herzog August Bibliothek Wolfenbüttel, Bc Sammelband 3:1 
4. Isaac Aboab da Fonseca

Amsterdam: David de Castro Tartas, 1693

לוח ספרים ... יצחק אבואב ... לחדש הששי הוא חדש יולייו שנת תק"ן ...

Catalogus variorum ... librorum ... D. Jsaaci Abuab ... [15] Julii 1693 ...

444 lots \& 114 lots in appendix

Amsterdam, UBA: BR RON 1187 (copy of JT s); Budapest, OszK 821.698; New York, JTS: RB380:3; Oxford, ASC: Stack 2nd SR.5o.d.2:5

5. Isaac d'Andrade Velosinos

The Hague: Abraham de Hondt, 1701

Catalogus instructissimae bibliothecae ... D. IsaaciD'Andrada, Velosinos ... 25 Aprilis $1701 \ldots$

2722 lots \& 949 lots in appendix

The Hague, HA: Hgst 5497; The Hague, HA: Hgst BNR 402-636; St Petersburg, NB: 16.20.9.6

6. David Nunes Torres

The Hague: Johannes Swart, 1728

Catalogus librorum ... David Nunes Torres ... 26 Julii 1728 ...

1556 lots

London, BL: SC 467:8

7. Solomon de Meza, alias Solomon Mendes Floris

Amsterdam, 1743

1052 lots (according to Shunami)

לוח ספרים ... שלמה די מיזה ... תק"ג ...

Holding place unknown. Shunami, no. 337

8. Manuel Lopes Suasso

The Hague: Nicolaas van Daalen, 1773

Catalogue ... de livres ... M.L. Suasso ... a la Haye ... 19Julliet 1773 ...

1135 lots \& 588 lots in appendix (pp. 93-96 are missing)

The Hague, кв: Verz. Cat. 36014

9. Judah de Benjamin Senior

Amsterdam: Jan Willem Smit, 1782

Catalogus van ... boeken ... Juda van Benjamin Senior ... 4 November 1782 ...

1271 lots (excluding the many non-book items from p. 56)

Leiden, UB: 1087 C 9; Washington, LC: Z997.B46

10. Aaron de Joseph de Pinto

Amsterdam: Jan Willem Smit, 1785

Catalogus van ... boeken ... Aron van Joseph de Pinto ... 21 Maart 1785 ...

2624 lots

St Petersburg, NB: 16.34.10.65:3 


\section{Saul Halevi}

Amsterdam: Widow and heirs Jacob Proops, 1786

$$
\text { רשימה מספרים ... שאול הלוי .. בק"ק האג יום ב'ח׳י אלול תקמ"ו.. }
$$

575 lots

The Hague, HA: Zc 5

12. Solomon Cohen Samuelsz

Amsterdam: Jacob Proops, 1786

רשימה מספרים ... בראטרדם יום ב'ו' לחדש אב תקמ"ו ...

Catalogus van ... boeken ... Salomon Cohen Samuelsz ... op den 31 July 1786 ... 2238 lots

Amsterdam, UBA: KVB Nv 494a; Amsterdam, UBA: BR Ros. Veil. 70

13. Abraham ben Isaac Keizer

Amsterdam: Widow Jacob Proops, 1796

רשימה מספרים ... מעזבון של ... אברהם בן המנוח כ' איציק קיזר ... באמשטרדם יום ב' כ' מרחשון תקנ"ז ...

265 lots

Amsterdam, UBA: BR Ros. Veil. 71

14. Jacob Isaac Levi, alias Jacob Leeuwarden

Amsterdam: Widow Jacob Proops, 1797

רשימה מספרים ... מעזבון ... יאקב לעוורדון ... בראטרדם ביום ג' כ"ט לחודש ניסן תקנ"ז... Catalogus van ... Boeken ... Jacob Isaac Levy, te Rotterdam ... op Dingsdag den 25 April 1797 ...

1647 lots

Amsterdam, ubA: Ros. Veil. 72; Amsterdam, Е 34 C $о 4$ (13); Utrecht, UB: C oct. 683; Jerusalem, NLI: 57 A 3323; London, BL: 1939.e.13.(7)

15. Abraham Martins

The Hague: Isaac van Cleef, Bernardus Scheurleer, and Jacques Detune, 1798

Catalogue des livres ... Abraham Martins ... le 26 Novembre 1798 ...

8814 lots

Amsterdam, uвA: кVв Nv 668; The Hague, кв: Verz. Cat. 3448; The Hague, MW: 140 C 27

16. David de Raphael Meldola

[Amsterdam] 1800

רשימה מספרי ... דאוויד דע רפאל מילדולא ... אשר ימכרו י"ג י"ד טבת תקס"א 754 lots (according to Shunami)

Amsterdam, EH 34 B 42 (25) [missing]; Shunami, no. 335

17. Abraham Judah Leib Mezritsch

The Hague: H.C. Susan and son, 1807.

רשימה מספרים ... אברהם יהודה ליב מעזריטש ... ק"ק האג ... ביום ג" כ"א מנחם תקס"ז ... 664 lots 
Amsterdam, UвA: Ros. Veil. 76; Ohio State University Z997.R45 1807; Jerusalem, NLI: 2013 A 6210 (copy Ohio State University)

18. Solomon Jessurun

Amsterdam: Belinfante en Comp., 1811

רשימה מספרים ... שלמה ישורון ... באמשטרדם ... בימים יא' יד' וטו' לחדש טבת ..

Catalogus van ... boeken ... Salomo Jessurun ... den 27sten December, 1811 ...

1075 lots in Hebrew part \& 1028 lots in Dutch part

Amsterdam, EH 14 D 26 (1); London, B L:1939.e.13.(5); Jerusalem, NLI: 8 = 43 A 700

19. Manuel Osorio

Amsterdam, 1811

[Catalogus ... Amsterdam]

Holding place unknown. Shunami, no. 354

2o. Loeb de Metz

[Amsterdam] 1813

רשימה מספרי ... ליב ... דע מעטץ ... תקע"ג ...

303 lots (according to Shunami)

Holding place unknown. Shunami, no. 339

21. Solomon ben Joel of Dubno

Amsterdam: Yohanan Levi Rofe and his son Benjamin, 1814

רשימה מספרים ... שלמה מדובנא ... ביום ד 'כ"ה תמוז תקע"ד ...

1182 lots

Amsterdam, ubA: Ros. Veil. 78; Amsterdam, UBA: Ros. Veil. 84; Amsterdam, EH 14 D 28; London, BL: 1939.e.7

22. Jacob Moses ben Saul Löwenstam \& anonymous

Amsterdam: David ben Jacob Proops and Solomon ben Abraham Proops, 1816

רשימה מספרים ... יעקב משה ... ועוד מעזבון אחר ... ביום ג'כ"א שבט תק"עו ..

701 lots in first part \& 385 lots in second part

London, BL: 1939.2.13.(4)

23. Moses Leman Jacobs, alias Moses Leime Winnig

Amsterdam: Yohanan Levi Rofe and his son Benjamin, 1819

רשימה ... משה בן כ"ה לימא ווינג ... חית ולמחרותו טית מרחשון תק"פ ....

Catalogus ... boeken ... Moses Leman Jacobs ... den 27 en 28 October 1819 ...

478 lots

Amsterdam, UBA: Ros. Veil. 82; Amsterdam, EH 28 B о3 (27) [missing]; Jerusalem, NLI: 93 A 5157

24. Daniel Cohen d'Azevedo

Amsterdam: David ben Jacob Proops and Solomon ben Abraham Proops, 1823

רשימה מספרים ... דניאל הכהן דאזיווידו ... ביום ג'ביום ד' י"ב וי"ג לחדש אלול תקפ"ג ... 758 lots

Amsterdam, UBA: Ros. Veil. 235; Amsterdam, EH 34 B 42 (25); Jerusalem, NLI: 8 = 43 A 701; London, BL: 1939.e.13.(1) 


\section{Meijer Liefmans}

Amsterdam: Yohanan Levi Rofe and his son Benjamin, 1825 רשימה מספרים ... מאיר ליפמאנס ... ביום ב'ג' כ"ז וכ"ח לחדש סיון תקפ"ה ... 1109 lots

Amsterdam, UBA: Ros. Veil. 236; Amsterdam, EH 21 E 89 (4); London, BL: 1939.e.13. (8)

26. Anshel ben Elijah Norden de Lima

Amsterdam: Van Embden \& co. and D. Proops Jacobsz, 1830

רשימה מספרים ... אנשיל בן ... אלי' נארדן לבית דעלימא ... ביום ד' וה' ,ב' וג' לחודש תמוז תק"צ ו...

674 lots

London, BL: 1939.e.13.(9)

\section{B Anonymous (Private Library) Sales Catalogues}

27. Anonymous

[Amsterdam?] 1747

רשימה מן ספרים שימכרו ביום ה'כ"ה בכסליו תק"ז לפ"ק 100 lots

Amsterdam, Rijksmuseum RP-P-2015-26-215O

28. Anonymous

[Amsterdam: Proops?] $175^{8}$

רשימה מכל מיני ספרים ... אמשטרדם .. ביום ד'ד'ג שבט תקי"ח ..

1301 lots

London, BL: 1939.f.16.(1)

29. Anonymous $=$ Van Emden

Amsterdam, $177^{2}$

רשימה מספרים ... ביום ג'ד' שהם י'ד וט'ו חשון תקל"ג ...

876 lots

Amsterdam, EH $34 \mathrm{C}$ o4 (10)

3o. Anonymous = Jacob Abanacker

[Amsterdam: Proops?] 1773

רשימת ספרים ... באמשטרדם ... ביום ב'וג' שהמה ה'ו' ניסן תקלג ...

400 lots (not complete)

Amsterdam, GAA: 334A, inv. no. 2417

31. Anonymous

Amsterdam: Jacobus Benedictus, [1775]

Catalogus van ... boeken ... den 3 en 4 de April 1775

535 lots

Amsterdam, GAA: Bibliotheek VC 3 
32. Anonymous $=$ Jacob Norden

Amsterdam: Widow and heirs Jacob Proops, 1784

רשימה מכל מיני ספרים ... ביום ב'וביום ג'ראש חודש טבת תקמ'ה ...

671 lots

London, BL: 1939.f.16.(2)

33. Anonymous $=$ Simon Boas

Amsterdam: Yohanan Levi Rofe and his son Benjamin, 1799

רשימה מספרים ... בהאג יום א׳ כ"ח לחדש איר תקנ"ט ...

507 lots

New York (NY), JTs Z999. R42 1799 (main part only)

אמפליאטיה על הרשימה מספרים ... ביום א׳ כ"ח אייר תקנ"ט לפ"ק ...

268 lots

Amsterdam, UBA: Ros. Veil. 73 (appendix only)

34. Anonymous

Amsterdam: Yohanan Levi Rofe and his son Benjamin, 1801

רשימה מספרים ... ביום ב' ב' דר"ח אלול תקס"א ...

877 lots

Amsterdam, EH 34 C 04 (17); Amsterdam, U BA: Ros. Veil. 74

35. Anonymous

Amsterdam: Yohanan Levi Rofe and his son Benjamin, 1802

רשימה מספרים ... ביום ב' כ"ט שבט תקס"ב ...

976 lots

Amsterdam, uBA: Ros. Veil. 75

36. Anonymous

Amsterdam: Widow and heirs Jacob Proops, 1802

מכירה מספרים ... ביום ב' י"א אדר שני תקס"ב ...

348 lots

Amsterdam, EH 34 C 04 (18)

37. Anonymous

Amsterdam: Widow and heirs Jacob Proops, 1802

רשימת ספרים ... ביום ד' י״א אלול ה תקס"ב ...

Catalogus van ... boeken ... den 8 september 1802 ...

349 lots in Hebrew part \& 355 lots in Dutch part

Amsterdam, EH 14 D 26 (2)

38. Anonymous

Amsterdam: Yohanan Levi Rofe and his son Benjamin, 1802

רשימה מספרים ... בהאג ביום ג'א' דר"ח חשון תקס"ג ...

787 lots

Amsterdam, EH 21 E 89 (2) 
39. $\quad$ Anonymous $=$ Arons $[\ldots]$

Amsterdam: Widow and heirs Jacob Proops, 1810

רשימה מספרים ... ביום ד' ג'אדר ראשון תקע ...

731 lots

Amsterdam, EH $34 \mathrm{C}$ o4 (16); Amsterdam, UBA: Ros. Veil. 77

40. Anonymous

Amsterdam: Jacob Cohen Belinfante, 1812

רשימה של ספרים ... ביום ג של שבת ז"לחדש חשון הבע"ל ...

Catalogus van ... boeken ...

362 lots in Hebrew part \& 185 lots in Dutch part

Amsterdam, EH $34 \mathrm{C} 04$ (14)

41. Anonymous

Amsterdam: David Proops, 1813

רשימה מספרים ... ביום ד' ד' אלול תקעג ...

372 lots

Amsterdam, EH 21 E 89 (3)

42. Anonymous

Amsterdam: Yohanan Levi Rofe and his son Benjamin, 1815

רשימה מספרים ... בק"ק האג יע"א ביום א' ז'אב תקע"ה ...

413 lots

Amsterdam, ubA: Ros. Veil. 79; Amsterdam, EH 34 C 04 (15); London, BL: 1939.e.12.(1)

43. Anonymous

Amsterdam: David ben Jacob Proops, 1819

רשימה מספרים ... ביום ג'יום ראשון לחדש חשון תקפ ...

Catalogus van ... boeken ... den 19 October 1819 ...

197 lots

Amsterdam, UBA: Ros. Veil. 83

44. Anonymous

Amsterdam: Solomon ben Abraham Proops, 1821

רשימה מספרים ... ביום ב' ד' לחודש סיון תקפא ...

255 lots \& 329 lots in appendix

Amsterdam, UBA: Ros. Veil. 81

45. Anonymous

Amsterdam: Yohanan Levi Rofe and his son Benjamin, 1822

רשימה מן ספרים ... באמשטרדם ביום ב'ג'לחדש ניסן ה תקפ"ב ...

429 lots in first part \& 492 lots in second part

Amsterdam, UBA: Ros. Veil. 8o; London, BL: 1939.e.12.(2) 
46. Anonymous

Amsterdam: David ben Jacob Proops, 1823

רשימה מספרים ... בק"ק האג ביום ג'ט"ו לחדש תמוז ...

556 lots

Amsterdam, UBA: Ros. Veil. 234; London, B L: 1939.e.12.(3)

47. $\quad$ Anonymous $=$ Mejuchas?

Amsterdam: Yohanan Levi Rofe and his son Benjamin, 1824

רשימה מן ספרים ... ביום ב'ח' לחדש אדר שני התקפ"ד ...

1007 lots

London, BL: 1939.e.12.(4)

48. Anonymous

Amsterdam: David ben Jacob Proops, 1825

רשימה מספרים ... ביום ב' וג', ב' דר"ח וב' אלול תקפה ...

1012 lots

London, BL: 1939.e.12.(6)

49. Anonymous

Amsterdam: Yohanan Levi Rofe and his son Benjamin, 1825

רשימה מספרים ... ביום ה'ט"ז סיון תקפ"ה ...

339 lots

London, BL: 1939.e.12.(5)

50. Anonymous

Amsterdam: J. van Embden and son, 1826

רשימה מן ספרים ... ביום ד' יד' תמוז תקפ"ו ...

265 lots

London, BL: 1939.e.12.(7)

51. Anonymous

Amsterdam: J. van Embden and son, 1827

רשימה מן ספרים ... ביום ג'וד', ב' וג' שבט ה תקפ"ז ...

1008 lots

London, BL: 1939.e.12.(8)

\section{Retail Stock or Wholesale Stock Catalogue}

52. Menasseh ben Israel

Amsterdam: [Menasseh ben Israel] 1648

[p. 1] Catalogus variorum librorum ... apud Menasseh Ben-Israel venales habentur / [p.12] Catalogus variorum ... librorum, qui typis Menasseh Ben-Israel impressi, apud ipsum venales habentur.

525 lots in first part \& 28 lots in second part

Köln, USB: GBI 405:d. Facsimile reprint in Fuks and Fuks-Mansfeld, 'Menasseh ben Israel as a bookseller', pp. 40-45 


\section{Samuel ben Israel Soeiro}

Amsterdam: [Samuel ben Israel Soeiro] $165^{2}$

Catalogo dos libros que Semuel ben Israel Soeiro, vende ...

67 lots

Holding place unknown. Facsimile reprint in Yaari, Studies in Hebrew Booklore, pp. 434-437

54. Anonymous $=$ Joseph Athias

Amsterdam: Henricus Wetstein, 1688

Catalogus van verscheyde ongebonde boeken.

25 lots

Amsterdam, GAA: Archief Deutzenhofje, 234, inv. no. 339

55. Isaac ben Abraham Cohen de Lara

Amsterdam: Isaac ben Abraham Cohen de Lara, 1704

Catalogo ... libros Espannoles y Portuguezes Judaycos ... a vender en casa del Autor. [last five unnumbered pages of:] Calendario Judayco De los Ros-Hodes ... 112 lots

Amsterdam, UBA: Ros. 19 E 2; Amsterdam, UBA: Ros. 1895 H 12 *

56. Isaac ben Abraham Cohen de Lara

Amsterdam: Isaac ben Abraham Cohen de Lara, 1704

Catalogo ... libros Españoles y Portuguezes ... a vender en casa del Autor. [pp. 69-89

of:] Guía para passageros ...

539 lots

Dresden, Sächsische Landesbibliothek: Geogr.B.345

57. Isaac Fundam

Amsterdam: [Isaac Fundam] 1724

Yshac Fundam Catálogo de libros y manuscritos españoles y portugueses ...

Holding place unkown. Bsco

58. Solomon ben Joseph Proops

Amsterdam: Solomon ben Joseph Proops, 1730

Appiryon Shelomo ...

Holding place unkown. Bsco; Shunami, no. 2907 